\title{
Chronic tonsillitis and biofilms: a brief overview of treatment modalities
}

This article was published in the following Dove Press journal:

Journal of Inflammation Research

\section{Muhamad Abu Bakar' \\ Judy McKimm² \\ Seraj Zohurul Haque ${ }^{3}$ \\ Md Anwarul Azim \\ Majumder ${ }^{4}$ \\ Mainul Haquel \\ 'Faculty of Medicine and Defence Health, Universiti Pertahanan Nasional Malaysia (National Defence University of Malaysia), Kuala Lumpur, Malaysia; ${ }^{2}$ Swansea University School of Medicine, Swansea University, Swansea, Wales, UK; ${ }^{3}$ University of Dundee, Ninewells Hospital \& Medical School, Dundee, UK; ${ }^{4}$ Faculty of Medical Sciences, The University of the West Indies, Wanstead, Barbados}

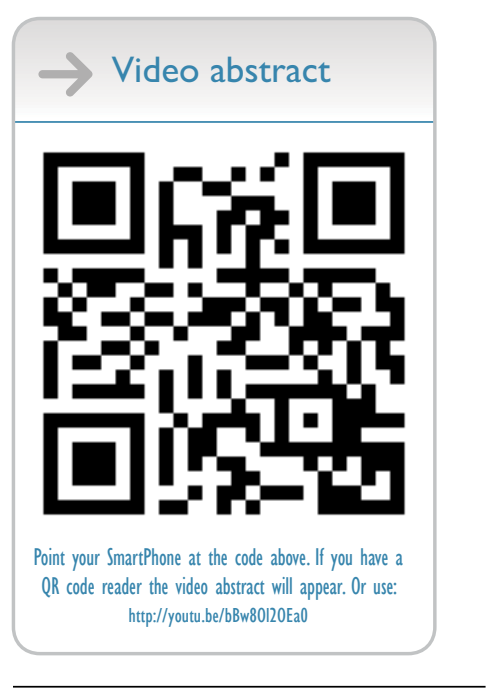

Correspondence: Mainul Haque Universiti Pertahanan Nasional Malaysia (National Defence University of Malaysia), Kem Perdana Sungai Besi, 57000 Kuala Lumpur, Malaysia

Tel +60 I 09265543

Email runurono@gmail.com

\begin{abstract}
Recurrent tonsillitis is described as when an individual suffers from several attacks of tonsillitis per year. Chronic and recurrent tonsillitis both cause repeated occurrences of inflamed tonsils which have a significant impact on a patient's quality of life. Numerous children suffer from recurrent tonsillitis and sore throats, and these illnesses become part of their life. Antimicrobials can provide temporary relief, but in many cases, tonsillitis recurs. The cause of such recurrent infections have been identified as microorganisms which often create biofilms and a repository of infection in the wet and warm folds of the tonsils. This review discusses different treatment modalities, their advantages and disadvantages, and new treatment options focusing on biofilms. All treatment options should be selected based on evidence and individual need.
\end{abstract}

Keywords: chronic, recurrent tonsillitis, inflammation, tonsillectomy

\section{Tonsillitis}

Tonsillitis is an inflammation of the pharyngeal tonsils. The inflammation may affect other areas of the back of the throat, including the adenoids and the lingual tonsils. Acute tonsillitis is an infection of the tonsils triggered by one of the several types of bacteria or viruses, and peritonsillar abscesses can also occur. Chronic tonsillitis is a tenacious infection of the tonsils which may result in tonsil stones. Recurrent tonsillitis ensues when an individual suffers from several incidents of tonsillitis per year. Both chronic and recurrent tonsillitis involve repeated occurrences of inflamed tonsils which can impact severely on a patient's quality of life. ${ }^{1,2}$ Children very often suffer from tonsillitis, although it is seldom observed below the age of 2 years. Tonsillitis due to Streptococcus bacteria classically happens in children aged between 5 and 15 years, while viral tonsillitis is more prevalent in younger children. ${ }^{3}$ Multiple studies report that the average prevalence of carrier status of school children for group A Streptococcus is $15.9 \%$. $^{4,5}$

\section{Epidemiology of tonsillitis}

Numerous children so often suffer from recurrent tonsillitis and sore throats that these illnesses become part of their life. For example, one study indicates that $\sim 30 \%$ of peritonsillar abscesses require a tonsillectomy, ${ }^{6}$ and another indicates that recurrent tonsillitis is reported in $11.7 \%$ and $12.1 \%$ of Norwegian and Turkish children, respectively. ${ }^{7}$ Many of these patients are prescribed antimicrobials which typically provide temporary relief, but then the tonsillitis recurs. ${ }^{8}$ Scientists working at Washington University School of 
Medicine identified that recurrent infections are exacerbated by the creation of biofilms by microorganisms in the wet and warm folds of the tonsils which act as a repository of infection. ${ }^{9}$ A study utilizing an innovative imagining technique in single sections of human mucosal tissue reports the presence of biofilms in $70.8 \%$ of chronic tonsillitis patients. ${ }^{10}$ Another study revealed that biofilms were recognized on the surface epithelium of tonsils and adenoids in many of the patients who were waiting for adenotonsillectomy due to chronic tonsillitis and adenoiditis. ${ }^{11}$ Such biofilms are also observed in other otorhinolaryngology-related infections such as chronic rhinosinusitis and chronic otitis media with effusion. ${ }^{12,13}$

\section{A brief overview of biofilms}

Biofilms are systematized communities of microorganisms embedded in a hydrated matrix of extracellular polymeric substances (EPSs) causing diverse persistent infections, including dental plaques, cystic fibrosis, urinary tract infections, osteomyelitis, and ear infections..$^{9,14,15}$ Biofilm formation is a prehistoric prokaryotic strategy of a microorganism to exist and grow in antagonistic settings through building innovative communities involving several processes. ${ }^{16-19}$ The Dutch scientist (commonly known as the Father of Microbiology) Antonie van Leeuwenhoek used his primitive but effective microscope to observe biofilms as early as 1674 and described aggregates of animalcules scraped from human tooth surfaces. ${ }^{20,21}$ The English phrase "survival of the fittest" arose from Darwinian evolutionary theory and describes one of the mechanisms of natural selection. ${ }^{22,23}$ Bacterial biofilm formation is a form of "survival of the fittest" under adverse conditions including chemical or antimicrobial treatment. ${ }^{24,25}$ The formation of biofilms by bacteria has three potential advantages: 1) "protection from harmful conditions in the host", 2) "sequestration to a nutrient-rich area", and 3) "utilization of cooperative benefits". ${ }^{26}$ Microbial biofilms were identified as a major cause of many human infections, and present in more than $65 \%-80 \%$ of all human bacterial infections. ${ }^{14,27-30}$ They pose "a serious problem for public health because of the increased resistance of biofilm-associated organisms to antimicrobial agents and the potential for these organisms to cause infections in patients with indwelling medical devices". ${ }^{31}$ Biofilm formation is generally considered to arise in four core stages: 1) attachment of bacteria to a surface, 2) microcolony formation, 3) biofilm maturation, and 4) detachment (also called dispersal) of bacteria which may then colonize new areas. ${ }^{32}$ Other research studies reports that the process of biofilm formation involves five stages: ${ }^{33-35} 1$ ) Microbial cells attach to surfaces reversibly. ${ }^{36}$ 2) Microbial cells then attach to surfaces irreversibly. ${ }^{37}$ 3) Cells get adsorbed on surfaces and grow into microcolonies; their physical dimensions are tens or hundreds of microns in diameter. ${ }^{38} 4$ ) The microbial fraternity grows into a three-dimensional configuration and settles down as a biofilm as cells replicate and the EPSs accumulate. ${ }^{39}$ 5) Bacterial cells detach from biofilm and disperse into the bulk fluid, where they act as free-swimming bacteria and form new biofilms. ${ }^{16,17}$ This process of biofilm formation is depicted in Figures 1 and 2.

\section{Distinct features of biofilm bacteria}

Bacteria found inside biofilms have distinct features different from those of free-swimming (planktonic) bacteria of

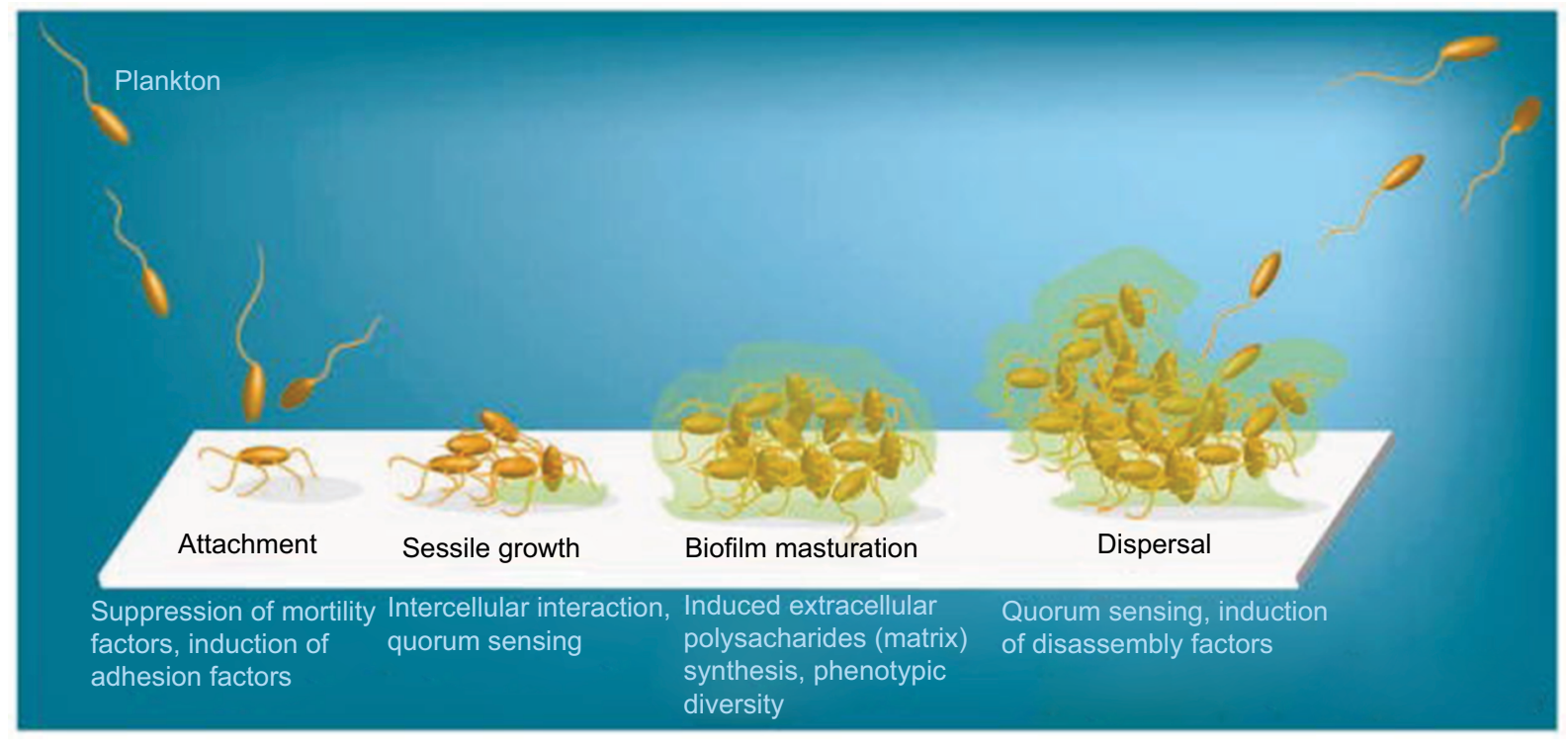

Figure I Four different stages of biofilm development.

Note: Islam MS, Richards JP, Ojha AK. Targeting drug tolerance in mycobacteria: a perspective from mycobacterial biofilms. Expert Rev Anti Infect Ther. 20I2; I0(9): 1055-1066, Taylor \& Francis Ltd, http://www.tandfonline.com reprinted by permission of the publisher. ${ }^{150}$ 


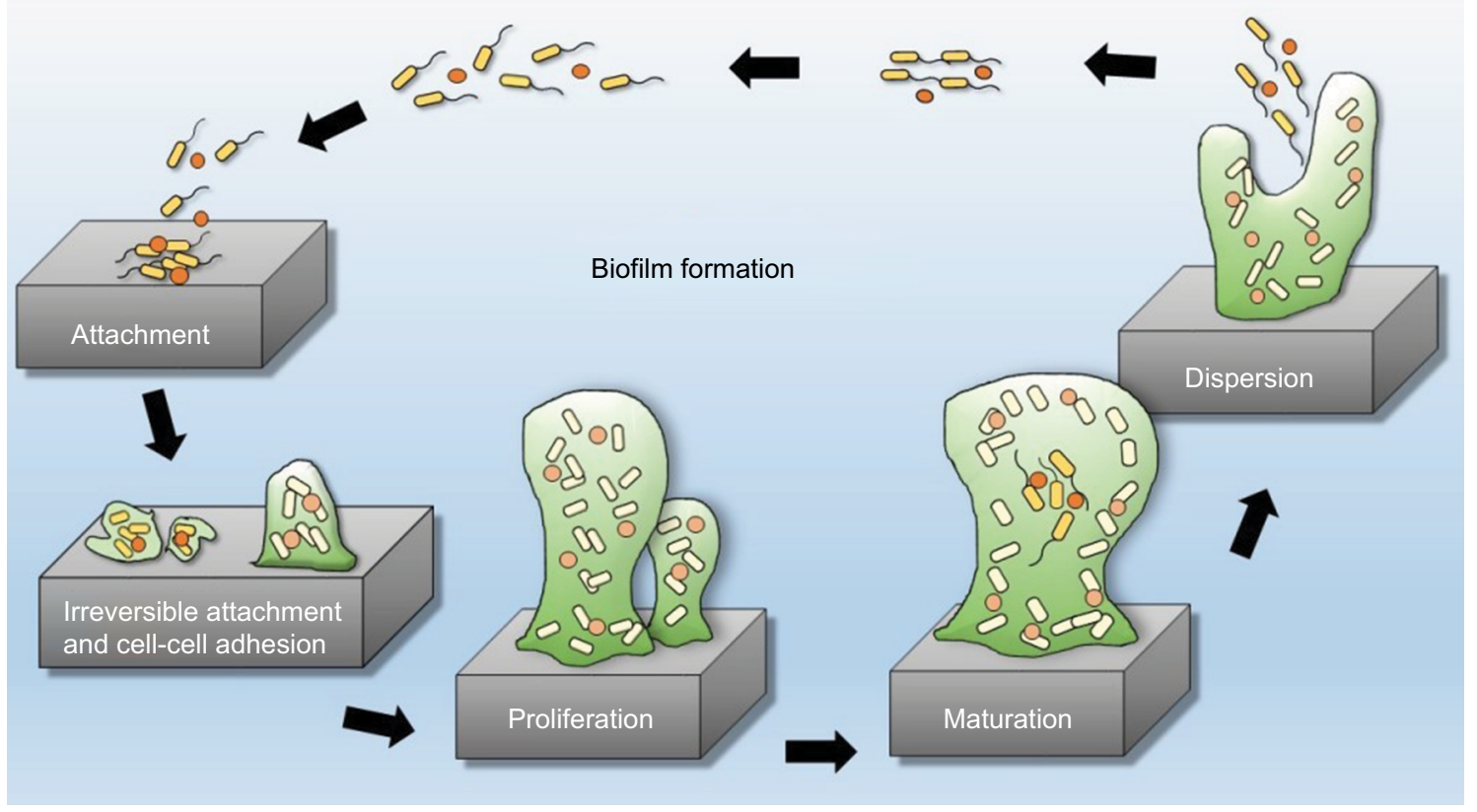

Figure 2 Five stages of biofilm development.

Note: Reproduced by permission from Perfectus Biomed Limited http://perfectusbiomed.com/cbe-meeting-anti-biofilm-technologies/. ${ }^{151}$

the same classes and possess a very high level of resistance to commonly used antimicrobial remedies, biocides and antiseptics, and the host immune response. ${ }^{40-42}$ Older, mature, and impenetrable biofilms are consistently more resistant to antimicrobials than younger, less dense biofilms. ${ }^{42}$ Bacterial cells residing in the outermost parts of the biofilm are more vulnerable to the host's defenses and antimicrobials, although these microorganisms possess numerous defensive mechanisms. The biofilm is formed of various microbial communities that create a complex three-dimensional physical barrier which hinders the diffusional penetration of antimicrobials..$^{17,43,44}$ The metabolic activity of the bacteria residing in the exterior layer of biofilm alters the local $\mathrm{pH}$ to be more acidic and creates anoxic zones that help to degrade antimicrobials. ${ }^{45-48}$ The biofilm also creates nutrient-depleted areas which act on microbes to put them into a stationary or dormant phase, which may also contribute toward antibiotic resistance. ${ }^{49,50}$ The extracellular matrix of the biofilm secretes polymers that bind and deactivate antimicrobials, forming an antibiotic "sink" ${ }^{51}$ These properties of biofilms (inadequate diffusion of nutrients, restricted antimicrobial transmission, and the alteration of the environment to produce a more hostile environment) combine to produce a widespread resistance and tolerance to antimicrobials. ${ }^{16,43-56}$ In addition, microbes entrenched in a biofilm can exist even in the presence of high concentrations of bactericidal antimicrobials, although they are abundantly sensitive to those antimicrobials in culture plates under planktonic conditions. ${ }^{57}$ This complex phenomenon is known as the "recalcitrance of biofilm bacteria toward antibiotics", 58 and microorganisms found in biofilms can be up to $500-1,000$ times more tolerant to antibacterial compounds than their planktonic counterparts. ${ }^{59-62}$ Additionally, many studies report that as soon as a biofilm is rooted and fixed, microbes develop resistance to several categories of physicochemical aggression, including ultraviolet light, heavy metals, low $\mathrm{pH}$, changes in hydration or salinity, and phagocytosis. ${ }^{63-67}$

\section{Recurrent tonsillitis and tonsillectomy}

Chronic tonsillitis affecting both children and adults is a serious health problem, ${ }^{68,69}$ and while the definition of severe recurrent tonsillitis varies, severity is described as five or more episodes of true tonsillitis a year, symptoms for at least a year, and episodes that are disabling and prevent normal functioning. ${ }^{70,71}$ In one study, the lifetime prevalence of recurrent tonsillitis is described as $11.7 \%(95 \% \mathrm{CI}$, $11.0 \%-12.3 \%$ ) with a significant preponderance of females. ${ }^{7}$ Recurrent tonsillitis is typically treated by either surgery or, when the patient does not meet tonsillectomy benchmarks or there are surgical or medical contraindications, by medical antimicrobial intervention. ${ }^{72,73}$

While tonsillectomy (surgical removal of the tonsils, with or without adenoidectomy) as a treatment modality has been practiced for over 100 years for children, much controversy exists around its value. As, for example, in 1951, the British Medical Journal reported that "it is better to delay a decision than to hurry it, and above all to avoid operating 
on tonsils which have been recently inflamed". ${ }^{74}$ One study showed that 0.6 episode of any type of a sore throat was reported in the first year after surgery compared to medical intervention, ${ }^{75}$ and another reported that surgery could lead to life-threatening complications. A Swedish cohort study reports that among post-tonsillectomy patients 20 years later, there was a higher incidence of "chronic, immune-mediated diseases ... in the operated group", with a statistically significant relationship between post-tonsillectomy and chronic disease, with a relative risk (RR) at 9.41 and a CI from 1 $(1.13<\mathrm{RR}<78.14) .{ }^{76}$ However, another research study focusing on adults found that tonsillectomy promotes and improves long-term health and quality of life, thus saving health resources. ${ }^{77}$

The decision to operate should therefore be taken with care based on an individual patient's needs and history, plus current research evidence. ${ }^{74,76,78,79}$ In making such decisions, secondary care doctors and family medicine practitioners need to collaborate because the decision whether a tonsillectomy is necessary is quite difficult and both the general practitioner (GP) and the otolaryngologist must contribute equally. ${ }^{74}$ The GP knows about the patient's frequency, duration, and severity of tonsillitis, whereas the ear, nose and throat specialist will evaluate symptoms relating to nasal and Eustachian impediment, and will assess whether symptoms are due to tonsillitis or chronic sinusitis. ${ }^{74}$

\section{Treatments aimed at disrupting biofilms}

Microbial biofilm formation is responsible for the development of acute-to-chronic infection in several diseases including cystic fibrosis, periodontitis, infective endocarditis, persistent otitis media, chronic rhinosinusitis, chronic tonsillitis, prostatitis, chronic osteomyelitis, atopic dermatitis, onychomycosis, dental caries, infectious kidney stones, and chronic wounds. ${ }^{80-83}$ Biofilms can also form on any surface, living or nonliving, even on clinical devices like pacemakers, implants, and catheters, and are very difficult to eradicate, which accentuates clinical consequences; for example, pseudomonal infections can affect any part of the human body. Furthermore, the microorganisms' adaptive capability and genetic changes within the biofilm lead to resistance to all known antimicrobial medicines. Pseudomonal infections in particular become really difficult to be treated and can threaten human life. ${ }^{83,84}$ It is thought that $99 \%$ of the biosphere's bacteria live in and that microbial communities gain an advantage living in this state. ${ }^{85}$ Consequently, microbial biofilms are thought to significantly affect human health by increasing morbidity, mortality, and health care cost. Biofilms not only add to hospital-acquired infections (HAIs) by increasing their chronicity and persistence but also colonize in other areas of the environment instigating corrosion, fouling of water pipes, and food and pharmaceutical decomposition. ${ }^{14,86-88}$ Another study reported that microbial biofilms can stick onto and infect all medical devices such as orthopedic prostheses and intravascular catheters and promote up to $60 \%$ of HAIs. ${ }^{89}$

Microorganisms in biofilms are distinctively more resistant to antimicrobial agents and environmental insults and are therefore very difficult to eradicate. ${ }^{42,90-94}$ Biofilms in general (and chronic tonsillitis specifically) can therefore lead to substantial economic costs for countries and individuals and health concerns and are an evolving public health problem in both high- and low-resource settings. ${ }^{77,95-100}$ For this reason, multiple research studies have attempted to resolve the issues of both biofilms and recurrent tonsillitis. ${ }^{59,61,101-108}$

The explosion of antibiotic resistance throughout the world of many microbial strains has put pressure on the research and medical communities to find an alternative strategy for the management of biofilm-mediated diseases. ${ }^{61}$ "Perhaps new antibiotics are not the only way to combat biofilm infections if we could make ineffective older antibiotics active again." ${ }^{59}$ In one study, a 2 -amino-imidazole molecule was developed which was capable of disrupting biofilms through making microorganisms which were previously antibiotic-resistant more vulnerable to older antimicrobials. ${ }^{59,62}$ Immunotherapy (using cyclic dinucleotides) has been effective in the management of different cancers, and this molecule has also been utilized as a therapeutic strategy for biofilm-related infections. Immunoprophylaxis and immunotherapy might therefore provide new tools to combat Staphylococcus epidermis biofilm formation. ${ }^{109,110}$ Recently, multiple studies revealed that a 3,5-cyclic diguanylic acid (c-di-GMP)-binding protein was found in biofilm communities. ${ }^{11,112} \mathrm{BdcA}$ (a protein that enhances biofilm dispersal) confiscates c-di-GMP and minimizes its local concentration and is partly responsible for the reduction and downregulation of EPSs of biofilms and for the upregulation of swimming, swarming, and planktonic microbes. ${ }^{111,112}$ This phenomenon has been observed in Pseudomonas sp. and Rhizobium meliloti biofilm communities. ${ }^{111,112}$ Multiple groups of scientists recently reported that $\mathrm{CdrA}$ (an adhesin compound) which is produced by biofilms in response to high levels of c-diGMP binds with Psl and stabilizes biofilm structure. ${ }^{38,106,113}$ Multiple research studies have identified at least three extracellular polysaccharides (Alginate, Pel, and Psl) that 
are important factors for structure maintenance and antibiotic resistance of biofilm. ${ }^{114-123}$ Another study revealed that exogenous addition of $\mathrm{D}$-amino acids ${ }^{109}$ disrupted preformed biofilms by disturbing adhesive fiber interactions and was also effective in preventing biofilm formation by Staphylococcus aureus and Pseudomonas aeruginosa. ${ }^{124-126}$ Another research study reported that biofilm-disassembly molecule is norspermidine which has a similar dispersal mechanism to D-amino acids by targeting the exopolysaccharides. ${ }^{125}$ The biofilm-inhibiting properties of norspermidine were detected in S. aureus and Escherichia coli pellicle biofilm. ${ }^{125}$ Current research therefore needs to focus on the development of norspermidine, BdcA, D-amino acids, and other polyamines as a novel antibiofilm approach, and medical communities should no longer depend exclusively on antimicrobials (which are increasingly ineffective with many pathogenic microorganisms because of resistance) and surgery to treat infectious diseases. ${ }^{104,111,112,124,125}$

Other studies have identified additional ways of disrupting biofilms. Bioactive enzymes such as dispersin or Proteinase $\mathrm{K}$ studied in orthopedic implants made bacteria more susceptible to antibiotics and finally eradicated the biofilm by affecting polymers or proteins of the biofilm structure. ${ }^{127}$ Several cytotoxic agents have also been found to successfully eliminate biofilms from implant surfaces, with citric acid being reported to be the most successful in eradicating biofilms on titanium surfaces. ${ }^{128}$ Multiple research studies have identified that electrical current can successfully detach $S$. aureus and $S$. epidermis biofilms from stainless steel implants. ${ }^{129-131}$ Another study observed that biofilms of $S$. epidermis on stainless steel fasteners were successfully eradicated through pulsed electromagnetic fields in combination with gentamicin. ${ }^{132}$ A new cluster of research studies have used laser-generated shockwaves to effectively break up biofilms. ${ }^{133}$ The technique was performed using a Q-switched, ND:YAG rhythmically laser functioning at a "rep rate of $10 \mathrm{~Hz}$ with $1500 \mathrm{~mJ}$ pulses centered at $1064 \mathrm{~nm}$. The laser pulses were used to create shockwave pulses in $\mathrm{Al}$ coated polycarbonate substrates and a resulting peak stress of greater than $50 \mathrm{MPa}$ " was able to reduce 55\% living microorganisms. ${ }^{134}$ The laser technique offers another way of disrupting biofilms and is useful in the management of infected wounds, where standard treatment modalities such as topical antimicrobials or the removal of dead, damaged, or infected tissue are unsuccessful or injurious. One study found that just 4-10 seconds of the laser therapy was able to disperse $97.9 \%$ of $P$. aeruginosa from biofilms on nitinol stents to single-celled planktonic microorganisms that can be more easily treated with antibiotics. ${ }^{135}$ Another found that laser-generated shockwaves therapy quickly disrupts the biofilms in infected wounds to eliminate the microorganisms and intensify the effectiveness of topical antimicrobials in the residual biofilm. Such interventions will promote patients' quality of life by reducing healing times and morbidity, and save health care costs. ${ }^{136}$

$N$-acetyl-cysteine (NAC) is an antioxidant mediator which reduces the variety of microbial bacteria on biofilm emergence and evolution, ${ }^{137}$ inhibits the manufacturing of the extracellular polysaccharide matrix, ${ }^{138}$ and promotes the disruption of mature biofilms. ${ }^{133} \mathrm{NAC}$ has been found to reduce Streptococcus pneumoniae and Haemophilus influenzae adhesion to human oropharyngeal epithelial cells in laboratory experiments. ${ }^{138}$ Chronic infections raise prostaglandin levels, and NAC effectively reduces these levels and helps to disrupt the biofilms. ${ }^{139-142}$ Correspondingly, aspirin-like non-steroidal anti-inflammatory drugs (NSAIDs) decrease biofilm production and completely block fungal infections. ${ }^{143}$ NAC interacts with the sulfhydryl group of enzymes involved in EPS production or excretion, which reduces the activity of these molecules or inhibits cysteine utilization. ${ }^{144}$ NAC, therefore, decreases in vitro biofilm formation, ${ }^{145}$ and other research on salicylates shows a similar negative effect on the production of biofilm. ${ }^{146} \mathrm{~A}$ study which applied both found that therapeutic doses of acetylsalicylic acid (ASA) and NAC diminish tonsillar mucosal biofilm formation in chronic or recurrent tonsillitis. ${ }^{102}$ Another Iraqi study found a strong correlation between the biofilm of Streptococcus pyogenes and recurrent tonsillitis and that three types of vinegar eradicated streptococcal biofilm remarkably: date (100\%), apple (95.5\%), and grape (90.9\%). ${ }^{105}$ A later study also demonstrated the potential of vinegar in eradicating tonsillar biofilm. ${ }^{101}$ In a laboratory experiment, while washing and cleaning with a soft brush did not remove the chronic tonsillitis biofilm layer on the tonsil surface, using a harder brush removed more biofilm. ${ }^{103}$ Researchers believe that the physical removal of biofilm (by brushing or using ultrasoundactivated bubbles) from the tonsil surface in vivo will lead to greater effectiveness of topical antimicrobials and decrease the need for systemic antimicrobials. ${ }^{103}$

\section{Conclusion}

Recurrent or chronic tonsillitis is currently a global public health issue which can severely impair an individual's quality of life. ${ }^{77,147}$ Microbial biofilms are a major cause of repeated tonsillitis in both pediatric and adult cohorts, and more research is needed to develop new treatment strategies. ${ }^{107,148,149}$ Treatment modalities should however be based on careful selection and 
individual consideration of the potential impact of biofilms on cases of recurrent tonsillitis. ${ }^{74}$ Rather than developing or using more potent antimicrobials, doctors should ensure they are upto-date with research and the treatment of biofilms, including the application of topical agents, the physical removal of biofilms, and other innovative treatments.

\section{Acknowledgments}

The authors are grateful to Dr Zakirul Islam, Associate Professor and Head of The Department, Pharmacology and Therapeutics, Eastern Medical College, Comilla, Bangladesh for his cooperation in converting the video abstract from a PowerPoint file to video format.

\section{Disclosure}

The authors report no conflict of interest in this work.

\section{References}

1. American Academy of Otolaryngology. Tonsillitis. 2018. Available from: http://www.entnet.org/content/tonsillitis. Accessed January 6, 2018.

2. Hayes K. Chronic and recurrent tonsillitis: what to know. 2017. Available from: https://www.verywell.com/chronic-and-recurrenttonsillitis-1191984. Accessed January 6, 2018.

3. Shah UK. Tonsillitis and peritonsillar abscess. Drugs \& Diseases. Otolaryngology and Facial Plastic Surgery. Medscape. Available from: https://emedicine.medscape.com/article/871977-overview\#a6. Accessed January 6, 2018.

4. Pichichero ME, Casey JR. Defining and dealing with carriers of group A Streptococci. Contemp Pediatr. 2003;20(1):46-53.

5. Wald ER. Commentary: antibiotic treatment of pharyngitis. Pediatr Rev. 2001;22(8):255-256.

6. Herzon FS. Harris P. Mosher Award thesis. Peritonsillar abscess: incidence, current management practices, and a proposal for treatment guidelines. Laryngoscope. 1995;105(8 Pt 3 Suppl 74):1-17.

7. Kvestad E, Kvaerner KJ, Roysamb E, Tambs K, Harris JR, Magnus P. Heritability of recurrent tonsillitis. Arch Otolaryngol Head Neck Surg. 2005;131(5):383-387.

8. Ward D. Bacterial biofilms may be source of recurrent tonsillitis. Medicine \& Health. Washington University in St. Louis. 2018. Available from: https://source.wustl.edu/2003/09/bacterial-biofilms-maybe-source-of-recurrent-tonsillitis/. Accessed January 6, 2018.

9. Chole RA, Faddis BT. Anatomical evidence of microbial biofilms in tonsillar tissues: a possible mechanism to explain chronicity. Arch Otolaryngol Head Neck Surg. 2003;129(6):634-636.

10. Kania RE, Lamers GE, Vonk MJ, et al. Demonstration of bacterial cells and glycocalyx in biofilms on human tonsils. Arch Otolaryngol Head Neck Surg. 2007;133(2):115-121.

11. Al-Mazrou KA, Al-Khattaf AS. Adherent biofilms in adenotonsillar diseases in children. Arch Otolaryngol Head Neck Surg. 2008;134(1):20-23.

12. Saylam G, Tatar EC, Tatar I, Özdek A, Korkmaz H. Association of adenoid surface biofilm formation and chronic otitis media with effusion. Arch Otolaryngol Head Neck Surg. 2010;136(6):550-555.

13. Sanderson AR, Leid JG, Hunsaker D. Bacterial biofilms on the sinus mucosa of human subjects with chronic rhinosinusitis. Laryngoscope. 2006;116(7):1121-1126.

14. Costerton JW, Stewart PS, Greenberg EP. Bacterial biofilms: a common cause of persistent infections. Science. 1999;284(5418):1318-1322.
15. Donlan RM, Costerton JW. Biofilms: survival mechanisms of clinically relevant microorganisms. Clin Microbiol Rev. 2002;15(2):167-193.

16. Hall-Stoodley L, Costerton JW, Stoodley P. Bacterial biofilms: from the environment to infectious disease. Nat Rev Microbiol. 2004;2(2): 95-108.

17. Hall-Stoodley L, Stoodley P. Biofilm formation and dispersal and the transmission of human pathogens. Trends Microbiol. 2005;13(1):7-10.

18. Purevdorj-Gage B, Costerton WJ, Stoodley P. Phenotypic differentiation and seeding dispersal in nonmucoid and mucoid Pseudomonas aeruginosa biofilms. Microbiology. 2005;151(Pt 5):1569-1576.

19. Mai-Prochnow A, Lucas-Elio P, Egan S, et al. Hydrogen peroxide linked to lysine oxidase activity facilitates biofilm differentiation and dispersal in several gram-negative bacteria. $J$ Bacteriol. 2008;190(15):5493-5501.

20. Borhan WM, Dababo MA, Thompson LD, Saleem M, Pashley N. Acute necrotizing herpetic tonsillitis: a report of two cases. Head Neck Pathol. 2015;9(1):119-122.

21. Slavkin HC. Biofilms, microbial ecology, and Antoni van Leeuwenhoek. J Am Dent Assoc. 1997;128(4):492-495.

22. Fasolo A. The Theory of Evolution and Its Impact. Milan: Springer; 2012.

23. Neumann JJ. The Role of Metaphor in the Darwin Debates: Natural Theology, Natural Selection, and Christian Production of CounterMetaphor [master's thesis]. College Station, TX: Texas A\&M University; 2012.

24. Tilahun A, Haddis S, Teshale A, Hadush T. Review on biofilm and microbial adhesion. Int J Microbiol Res. 2016;7(3):63-73.

25. Brown MRW, Gilbert P. Microbiological Quality Assurance: A Guide Towards Relevance and Reproducibility of Inocula. Boca Raton, NY: CRC Press; 1995.

26. Jefferson KK. What drives bacteria to produce a biofilm? FEMS Microbiol Lett. 2004;236(2):163-173.

27. Chambers JR, Sauer K. The MerR-like regulator BrlR impairs Pseudomonas aeruginosa biofilm tolerance to colistin by repressing PhoPQ. J Bacteriol. 2013;195(20):4678-4688.

28. Joo HS, Otto M. Molecular basis of in-vivo biofilm formation by bacterial pathogens. Chem Biol. 2012;19(12):1503-1513.

29. Lebeaux D, Chauhan A, Rendueles O, Beloin C. From in vitro to in vivo models of bacterial biofilm-related infections. Pathogens. 2013;2(2):288-356.

30. Costerton JW. Introduction to biofilm. Int J Antimicrob Agents. 1999;11(3-4):217-221.

31. Donlan RM. Biofilm formation: a clinically relevant microbiological process. Clin Infect Dis. 2001;33(8):1387-1392.

32. Landini P, Antoniani D, Burgess JG, Nijland R. Molecular mechanisms of compounds affecting bacterial biofilm formation and dispersal. Appl Microbiol Biotechnol. 2010;86(3):813-823.

33. Renner LD, Weibel DB. Physicochemical regulation of biofilm formation. MRS Bull. 2011;36(5):347-355.

34. Banerjee P, Singh M, Sharma V. Biofilm formation: a comprehensive review. Int J Pharm Res Health Sci. 2015;3(2):556-560.

35. Sauer K, Camper AK, Ehrlich GD, Costerton JW, Davies DG. Pseudomonas aeruginosa displays multiple phenotypes during development as a biofilm. $J$ Bacteriol. 2002;184(4):1140-1154.

36. Thomas WE, Nilsson LM, Forero M, Sokurenko EV, Vogel V. Sheardependent "stick-and-roll" adhesion of type 1 fimbriated Escherichia coli. Mol Microbiol. 2004;53(5):1545-1557.

37. Flemming HC, Wingender J. The biofilm matrix. Nat Rev Microbiol. 2010;8(9):623-633.

38. Borlee BR, Goldman AD, Murakami K, Samudrala R, Wozniak DJ, Parsek MR. Pseudomonas aeruginosa uses a cyclic-di-GMP-regulated adhesin to reinforce the biofilm extracellular matrix. Mol Microbiol. 2010;75(4):827-842.

39. Alpkvist E, Picioreanu C, van Loosdrecht MC, Heyden A. Threedimensional biofilm model with individual cells and continuum EPS matrix. Biotechnol Bioeng. 2006;94(5):961-979. 
40. Hentzer M, Givskov M. Pharmacological inhibition of quorum sensing for the treatment of chronic bacterial infections. J Clin Invest. 2003;112(9):1300-1307.

41. Chole RA, Faddis BT. Evidence for microbial biofilms in cholesteatomas. Arch Otolaryngol Head Neck Surg. 2002;128(10):1129-1133.

42. Stewart PS. Antimicrobial tolerance in biofilms. Microbiol Spectr. 2015;3(3):10.

43. McConoughey SJ, Howlin R, Granger JF, et al. Biofilms in periprosthetic orthopedic infections. Future Microbiol. 2014;9(8):987-1007.

44. Stoodley P, Sauer K, Davies DG, Costerton JW. Biofilms as complex differentiated communities. Annu Rev Microbiol. 2002;56:187-209.

45. Huang CT, Yu FP, McFeters GA, Stewart PS. Nonuniform spatial patterns of respiratory activity within biofilms during disinfection. Appl Environ Microbiol. 1995;61(6):2252-2256.

46. de Beer D, Stoodley P. Relation between the structure of an aerobic biofilm and mass transport phenomena. Water Sci Technol. 1995;32(8):11-18.

47. de Beer D, Stoodley P, Lewandowski Z. Measurement of local diffusion coefficients in biofilms by microinjection and confocal microscopy. Biotechnol Bioeng. 1997;53(2):151-158.

48. Stoodley P, Wefel J, Gieseke A, DeBeer D, von Ohle C. Biofilm plaque and hydrodynamic effects on mass transfer, fluoride delivery, and caries. J Am Dent Assoc. 2008;139(9):1182-1190.

49. Walters MC 3rd, Roe F, Bugnicourt A, Franklin MJ, Stewart PS. Contributions of antibiotic penetration, oxygen limitation, and low metabolic activity to tolerance of Pseudomonas aeruginosa biofilms to ciprofloxacin and tobramycin. Antimicrob Agents Chemother. 2003;47(1):317-332.

50. Fux CA, Wilson S, Stoodley P. Detachment characteristics and oxacillin resistance of Staphylococcus aureus biofilm emboli in an in vitro catheter infection model. J Bacteriol. 2004;186(14):4486-4491.

51. Høiby N. Recent advances in the treatment of Pseudomonas aeruginosa infections in cystic fibrosis. BMC Med. 2011;9:32.

52. Anwar H, Strap JL, Costerton JW. Establishment of aging biofilms: a possible mechanism of bacterial resistance to antimicrobial therapy. Antimicrob Agents Chemother. 1992;36(7):1347-1351.

53. Borriello G, Werner E, Roe F, Kim AM, Ehrlich GD, Stewart PS. Oxygen limitation contributes to antibiotic tolerance of Pseudomonas aeruginosa in biofilms. Antimicrob Agents Chemother. 2004;48(7):2659-2664.

54. Brown MR, Allison DG, Gilbert P. Resistance of bacterial biofilms to antibiotics: a growth-rate related effect? J Antimicrob Chemother. 1988;22(6):777-783.

55. Shah D, Zhang Z, Khodursky A, Kaldalu N, Kurg K, Lewis K. Persisters: a distinct physiological state of E. coli. BMC Microbiol. 2006;12:53.

56. Stewart PS, Costerton JW. Antibiotic resistance of bacteria in biofilms. Lancet. 2001;358(9276):135-138.

57. Anderl JN, Franklin MJ, Stewart PS. Role of antibiotic penetration limitation in Klebsiella pneumoniae biofilm resistance to ampicillin and ciprofloxacin. Antimicrob Agents Chemother. 2000;44(7):1818-1824.

58. Lebeaux D, Ghigo JM, Beloin C. Biofilm-related infections: bridging the gap between clinical management and fundamental aspects of recalcitrance toward antibiotics. Microbiol Mol Biol Rev. 2014;78(3):510-543.

59. Potera C. Antibiotic resistance: biofilm dispersing agent rejuvenates older antibiotics. Environ Health Perspect. 2010;118(7):A288.

60. Sedlacek MJ, Walker C. Antibiotic resistance in an in vitro subgingival biofilm model. Oral Microbiol Immunol. 2007;22(5):333-339.

61. Worthington RJ, Richards JJ, Melander C. Small molecule control of bacterial biofilms. Org Biomol Chem. 2012;10(37):7457-7474.

62. Rogers SA, Huigens RW 3rd, Cavanagh J, Melander C. Synergistic effects between conventional antibiotics and 2-aminoimidazole-derived antibiofilm agents. Antimicrob Agents Chemother. 2010;54(5):2112-2118

63. Espeland EM, Wetzel RG. Complexation, stabilization, and UV photolysis of extracellular and surface-bound glucosidase and alkaline phosphatase: implications for biofilm microbiota. Microb Ecol. 2001;42(4):572-585.
64. Le Magrex-Debar E, Lemoine J, Gelle MP, Jacquelin LF, Choisy C. Evaluation of biohazards in dehydrated biofilms on foodstuff packaging. Int J Food Microbiol. 2000;55(1-3):239-243.

65. Leid JG, Shirtliff ME, Costerton JW, Stoodley P. Human leukocytes adhere to, penetrate, and respond to Staphylococcus aureus biofilms. Infect Immun. 2002;70(11):6339-6345.

66. McNeill K, Hamilton IR. Acid tolerance response of biofilm cells of Streptococcus mutans. FEMS Microbiol Lett. 2003;221(1):25-30.

67. Teitzel GM, Parsek MR. Heavy metal resistance of biofilm and planktonic Pseudomonas aeruginosa. Appl Environ Microbiol. 2003;69(4):2313-2320.

68. Wagner S, Jung H, Nau F, Schmitt H. Relevance of infectious diseases in a pediatric practice. Klin Padiatr. 1993;205(1):14-17.

69. Potera C. Forging a link between biofilms and disease. Science. 1999;283(5409):1837-1839.

70. Management of sore throat and indications for tonsillectomy. National Clinical Guideline No. 34. Edinburgh: Scottish Intercollegiate Guidelines Network, Royal College of Physicians. Available from: http:// www.sdl.academic.chula.ac.th/Sore\%20Throat/Sign.pdf. Accessed January 11, 2018.

71. McKerrow WS. Recurrent tonsillitis. Am Fam Physician. 2002;66(9): 1735-1736.

72. El Hennawi DED, Geneid A, Zaher S, Ahmed MR. Management of recurrent tonsillitis in children. Am J Otolaryngol. 2017;38(4):371-374.

73. Georgalas CC, Tolley NS, Narula A. Tonsillitis. BMJ Clin Evid. 2009;2009:0503.

74. Gale AH. Refresher course for general practitioners: pros and cons of tonsillectomy. $\mathrm{Br}$ Med J. 1951;1(4698):133-135.

75. Burton MJ, Glasziou PP, Chong LY, Venekamp RP. Tonsillectomy or adenotonsillectomy versus non-surgical treatment for chronic/ recurrent acute tonsillitis. Cochrane Database Syst Rev. 2014;19(11): CD001802.

76. Johansson E, Hultcrantz E. Tonsillectomy-clinical consequences twenty years after surgery? Int J Pediatr Otorhinolaryngol. 2003;67(9):981-988.

77. Senska G, Atay H, Pütter C, Dost P. Long-term results from tonsillectomy in adults. Dtsch Arztebl Int. 2015;112(50):849-855.

78. Stuck BA, Götte K, Windfuhr JP, Genzwürker H, Schroten H, Tenenbaum T. Tonsillectomy in children. Dtsch Arztebl Int. 2008;105(49): $852-861$.

79. Windfuhr JP. Indications for tonsillectomy stratified by the level of evidence. GMS Curr Top Otorhinolaryngol Head Neck Surg. 2016;15:Doc09.

80. Aparna MS, Yadav S. Biofilms: microbes and disease. Braz J Infect Dis. 2008;12(6):526-530.

81. Soto SM. Importance of biofilms in urinary tract infections: new therapeutic approaches. Adv Biol. 2014;2014:543974.

82. Zhao G, Usui ML, Lippman SI, et al. Biofilms and inflammation in chronic wounds. Adv Wound Care (New Rochelle). 2013;2(7):389-399.

83. Reyes-Darias JA, Krell T. Riboswitches as potential targets for the development of anti-biofilm drugs. Curr Top Med Chem. 2017;17(17): 1945-1953.

84. Sharma G, Rao S, Bansal A, Dang S, Gupta S, Gabrani R. Pseudomonas aeruginosa biofilm: potential therapeutic targets. Biologicals 2014;42(1):1-7.

85. Donlan RM. New approaches for the characterization of prosthetic joint biofilms. Clin Orthop Relat Res. 2005;437:12-19.

86. Figueiredo AMS, Ferreira FA, Beltrame CO, Côrtes MF. The role of biofilms in persistent infections and factors involved in ica-independent biofilm development and gene regulation in Staphylococcus aureus. Crit Rev Microbiol. 2017;43(5):602-620.

87. Zumstein V, Betschart P, Albrich WC, et al. Biofilm formation on ureteral stents - incidence, clinical impact, and prevention. Swiss Med Wkly. 2017;147:w14408.

88. Vickery K, Hu H, Jacombs AN, Bradshaw DA, Deva AK. A review of bacterial biofilms and their role in device associated infection. Healthc Infect. 2013;18(2):61-66.

89. Bryers JD. Medical biofilms. Biotechnol Bioeng. 2008;100(1):1-18. 
90. Lewis K. Riddle of biofilm resistance. Antimicrob Agents Chemother. 2001;45(4):999-1007.

91. Spoering AL, Lewis K. Biofilms and planktonic cells of Pseudomonas aeruginosa have similar resistance to killing by antimicrobials. $J$ Bacteriol. 2001;183(23):6746-6751.

92. Davey ME, O'toole GA. Microbial biofilms: from ecology to molecular genetics. Microbiol Mol Biol Rev. 2000;64(4):847-867.

93. Bridier A, Briandet R, Thomas V, Dubois-Brissonnet F. Resistance of bacterial biofilms to disinfectants: a review. Biofouling. 2011;27(9): 1017-1032.

94. El Khatib M, Tran QT, Nasrallah C, et al. Providencia stuartii form biofilms and floating communities of cells that display high resistance to environmental insults. PLoS One. 2017;12(3):e0174213.

95. Zhou G, Shi QS, Huang XM, Xie XB. The three bacterial lines of defense against antimicrobial agents. Int J Mol Sci. 2015;16(9):21711-21733.

96. Fish KE, Osborn AM, Boxall J. Characterizing and understanding the impact of microbial biofilms and the extracellular polymeric substance (EPS) matrix in drinking water distribution systems. Environ Sci Water Res Technol. 2016;2:614-630.

97. Sadekuzzaman M, Yang S, Mizan MFR, Ha SD. Current and recent advanced strategies for combating biofilms. Comp Rev Food Sci Food Safety. 2015;14(4):491-509.

98. Zhao X, Zhaoa F, Wang J, Zhong Z. Biofilm formation and control strategies of foodborne pathogens: food safety perspectives. RSCAdv. 2017;7:36670-36683.

99. Duarte VM, McGrath CL, Shapiro NL, Bhattacharrya N. Healthcare costs of acute and chronic tonsillar conditions in the pediatric population in the United States. Int J Pediatr Otorhinolaryngol. 2015;79(6):921-925.

100. Stelter K. Tonsillitis and sore throat in children. GMS Curr Top Otorhinolaryngol Head Neck Surg. 2014;13:Doc07.

101. Al-Saadi MAK, Abdul-Lateef LA, Kareem MA. Detection of biofilm formation and effect of vinegar on biofilm of Streptococcus pyogenes isolated from patients with tonsillitis. Int $J$ Pharm Tech Res. 2016;9(9):236-242.

102. Bulut F, Meric F, Yorgancilar E, et al. Effects of N-acetyl-cysteine and acetylsalicylic acid on the tonsil bacterial biofilm tissues by light and electron microscopy. Eur Rev Med Pharmacol Sci. 2014;18(23):3720-3725.

103. Ciftci Z, Develioglu O, Arbak S, Ozdoganoglu T, Gultekin E. A new horizon in the treatment of biofilm-associated tonsillitis. Ther Adv Respir Dis. 2014;8(3):78-83.

104. Connaughton A, Childs A, Dylewski S, Sabesan VJ. Biofilm disrupting technology for orthopedic implants: what's on the horizon? Front Med. 2014;1:22.

105. Ismael NF. "Vinegar" as anti-bacterial biofilm formed by Streptococcus pyogenes isolated from recurrent tonsillitis patients, in vitro. Jordan J Biol Sci. 2013;6(3):191-197.

106. Kostakioti M, Hadjifrangiskou M, Hultgren SJ. Bacterial biofilms: development, dispersal, and therapeutic strategies in the dawn of the postantibiotic era. Cold Spring Harb Perspect Med. 2013;3(4):a010306.

107. Römling U, Balsalobre C. Biofilm infections, their resilience to therapy and innovative treatment strategies. J Intern Med. 2012;272(6): $541-561$.

108. Wu H, Moser C, Wang HZ, Høiby N, Song ZJ. Strategies for combating bacterial biofilm infections. Int J Oral Sci. 2015;7(1):1-7.

109. Topalian SL, Weiner GJ, Pardoll DM. Cancer immunotherapy comes of age. J Clin Oncol. 2011;29(36):4828-4836.

110. Van Mellaert L, Shahrooei M, Hofmans D, Eldere JV. Immunoprophylaxis and immunotherapy of Staphylococcus epidermidis infections: challenges and prospects. Expert Rev Vaccines. 2012;11(3):319-334.

111. Ma Q, Guishan Z, Wood TK. Escherichia coli BdcA controls biofilm dispersal in Pseudomonas aeruginosa and Rhizobium meliloti. BMC Res Notes. 2011;4:447.

112. Ma Q, Yang Z, Pu M, Peti W, Wood TK. Engineering a novel c-diGMP-binding protein for biofilm dispersal. Environ Microbiol. 2011;13(3):631-642.
113. Ha DG, O'Toole GA. c-di-GMP and its effects on biofilm formation and dispersion: a Pseudomonas aeruginosa review. Microbiol Spectr. 2015;3(2):10.

114. Friedman L, Kolter R. Genes involved in matrix formation in Pseudomonas aeruginosa PA14 biofilms. Mol Microbiol. 2004;51(3):675-690.

115. Friedman L, Kolter R. Two genetic loci produce distinct carbohydraterich structural components of the Pseudomonas aeruginosa biofilm matrix. $J$ Bacteriol. 2004;186(14):4457-4465.

116. Jackson KD, Starkey M, Kremer S, Parsek MR, Wozniak DJ. Identification of psl, a locus encoding a potential exopolysaccharide that is essential for Pseudomonas aeruginosa PAO1 biofilm formation. J Bacteriol. 2004;186(14):4466-4475.

117. Matsukawa M, Greenberg EP. Putative exopolysaccharide synthesis genes influence Pseudomonas aeruginosa biofilm development. J Bacteriol. 2004;186(14):4449-4456.

118. Ma L, Jackson KD, Landry RM, Parsek MR, Wozniak DJ. Analysis of Pseudomonas aeruginosa conditional psl variants reveals roles for the psl polysaccharide in adhesion and maintaining biofilm structure post attachment. J Bacteriol. 2006;188(23):8213-8221.

119. Vasseur P, Vallet-Gely I, Soscia C, Genin S, Filloux A. The pel genes of the Pseudomonas aeruginosa PAK strain are involved at early and late stages of biofilm formation. Microbiology. 2005;151(Pt 3): 985-997.

120. Colvin KM, Irie Y, Tart CS, et al. The Pel and Psl polysaccharides provide Pseudomonas aeruginosa structural redundancy within the biofilm matrix. Environ Microbiol. 2012;14(8):1913-1928.

121. Wei Q, Ma LZ. Biofilm matrix and its regulation in Pseudomonas aeruginosa. Int J Mol Sci. 2013;14(10):20983-21005.

122. Franklin MJ, Nivens DE, Weadge JT, Howell PL. Biosynthesis of the Pseudomonas aeruginosa extracellular polysaccharides, alginate, Pel, and Psl. Front Microbiol. 2011;2:167.

123. Limoli DH, Jones CJ, Wozniak DJ. Bacterial extracellular polysaccharides in biofilm formation and function. Microbiol Spectr. 2015;3(3):10.

124. Fujii N. D-amino acids in living higher organisms. Orig Life Evol Biosph. 2002;32(2):103-127.

125. Kolodkin-Gal I, Romero D, Cao S, Clardy J, Kolter R, Losick R. D-amino acids trigger biofilm disassembly. Science. 2010;328(5978): 627-629.

126. Cava F, Lam H, de Pedro MA, Waldor MK. Emerging knowledge of regulatory roles of D-amino acids in bacteria. Cell Mol Life Sci. 2010;68(5):817-831.

127. Campoccia D, Montanaro L, Arciola CR. A review of the biomaterials technologies for infection-resistant surfaces. Biomaterials. 2013;34(34):8533-8554.

128. Ntrouka VI, Slot DE, Louropoulou A, Van der Weijden F. The effect of chemotherapeutic agents on contaminated titanium surfaces: a systematic review. Clin Oral Implants Res. 2011;22(7):681-690.

129. Ercan B, Kummer KM, Tarquinio KM, Webster TJ. Decreased Staphylococcus aureus biofilm growth on anodized nanotubular titanium and the effect of electrical stimulation. Acta Biomater. 2011;7(7):3003-3012.

130. Del Pozo JL, Rouse MS, Euba G, et al. The electricidal effect is active in an experimental model of Staphylococcus epidermidis chronic foreign body osteomyelitis. Antimicrob Agents Chemother. 2009;53(10):4064-4068.

131. van der Borden AJ, van der Mei HC, Busscher HJ. Electric block current induced detachment from surgical stainless steel and decreased viability of Staphylococcus epidermidis. Biomaterials. 2005;26(33):6731-6735.

132. Pickering SA, Bayston R, Scammell BE. Electromagnetic augmentation of antibiotic efficacy in infection of orthopedic implants. $J$ Bone Joint Surg Br. 2003;85(4):588-593.

133. Hansen EN, Zmistowski B, Parvizi J. Periprosthetic joint infection: what is on the horizon? Int J Artif Organs. 2012;35(10):935-950.

134. Taylor ZD, Navarro A, Kealey CP, et al. Bacterial biofilm disruption using laser-generated shockwaves. Conf Proc IEEE Eng Med Biol Soc. 2010;2010:1028-1032. 
135. Kizhner V, Krespi YP, Hall-Stoodley L, Stoodley P. Laser-generated shockwave for clearing medical device biofilms. Photomed Laser Surg. 2011;29(4):277-282.

136. Francis NC, Yao W, Grundfest WS, Taylor ZD. Laser-generated shockwaves as a treatment to reduce bacterial load and disrupt biofilm. IEEE Trans Biomed Eng. 2017;64(4):882-889.

137. Schwandt LQ, Van Weissenbruch R, Stokroos I, Van Der Mei HC, Busscher HJ, Albers FW. Prevention of biofilm formation by dairy products and $\mathrm{N}$-acetylcysteine on voice prostheses in an artificial throat. Acta Otolaryngol. 2004;124(6):726-731.

138. Riise GC, Qvarfordt I, Larsson S, Eliasson V, Andersson BA. Inhibitory effect of $\mathrm{N}$-acetylcysteine on adherence of Streptococcus pneumoniae and Haemophilus influenzae to human oropharyngeal epithelial cells in vitro. Respiration. 2000;67:552-558.

139. Ricciotti E, FitzGerald GA. Prostaglandins and inflammation. Arterioscler Thromb Vasc Biol. 2011;31(5):986-1000.

140. Kiecolt-Glaser JK. Stress, food, and inflammation: psychoneuroimmunology and nutrition at the cutting edge. Psychosom Med. 2010;72(4):365-369.

141. Hsieh CC, Hsieh SC, Chiu JH, Wu YL. Protective effects of N-acetylcysteine and a prostaglandin E1 analog, alprostadil, against hepatic ischemia: reperfusion injury in rats. $J$ Tradit Complement Med. 2014;4(1):64-71

142. Blasi F, Page C, Rossolini GM, et al. The effect of N-acetylcysteine on biofilms: implications for the treatment of respiratory tract infections. Respir Med. 2016;117:190-197.

143. Witkin SS, Jeremias J, Ledger WJ. A localized vaginal allergic response in women with recurrent vaginitis. J Allergy Clin Immunol. 1988;81(2):412-416.
144. Alem MA, Douglas LJ. Effects of aspirin and other nonsteroidal anti-inflammatory drugs on biofilms and planktonic cells of Candida albicans. Antimicrob Agents Chemother. 2004:48(1):41-47.

145. Pe'Rez-Giraldo C, Rodriguez-Benito A, Moran FJ, Hurtado C, Blanco MT, Gomez-Garcia AC. Influence of N-acetylcysteine on the formation of biofilm by Staphylococcus epidermidis. J Antimicrob Chemother. 1997;39(5):643-646.

146. Xu XM, Sansores-Garcia L, Chen XM, Matijevic-Aleksic N, Du M, Wu KK. Suppression of inducible cyclooxygenase 2 gene transcription by aspirin and sodium salicylate. Proc Natl Acad Sci U S A. 1999;96(9):5292-5297.

147. Torretta S, Rosazza C, Pace ME, Iofrida E, Marchisio P. Impact of adenotonsillectomy on pediatric quality of life: review of the literature. Ital J Pediatr. 2017;43(1):107.

148. Alasil SM, Omar R, Ismail S, Yusof MY, Dhabaan GN, Abdulla MA. Evidence of bacterial biofilms among infected and hypertrophied tonsils in correlation with the microbiology, histopathology, and clinical symptoms of tonsillar diseases. Int J Otolaryngol. 2013;2013:408238

149. Torrettaa S, Lorenzo Drago L, Marchisio P, et al. Recurrences in chronic tonsillitis substained by tonsillar biofilm-producing bacteria in children. Relationship with the grade of tonsillar hyperplasy. Int $J$ Pediatr Otorhinolaryngol. 2013;77(2):200-204.

150. Islam MS, Richards JP, Ojha AK. Targeting drug tolerance in mycobacteria: a perspective from mycobacterial biofilms. Expert Rev Anti Infect Ther. 2012;10(9):1055-1066.

151. CBE Regulatory Meeting: Anti-Biofilm Technologies: Pathways to Product Development [webpage on the Internet]. Perfectus Biomed 2013. Available from http://perfectusbiomed.com/cbe-meeting-antibiofilm-technologies/. Accessed July 23, 2018.
Journal of Inflammation Research

\section{Publish your work in this journal}

The Journal of Inflammation Research is an international, peer-reviewed open access journal that welcomes laboratory and clinical findings on the molecular basis, cell biology and pharmacology of inflammation including original research, reviews, symposium reports, hypothesis formation and commentaries on: acute/chronic inflammation; mediators of

\section{Dovepress}

inflammation; cellular processes; molecular mechanisms; pharmacology and novel anti-inflammatory drugs; clinical conditions involving inflammation. The manuscript management system is completely online and includes a very quick and fair peer-review system. Visit http://www.dove press.com/testimonials.php to read real quotes from published authors. 